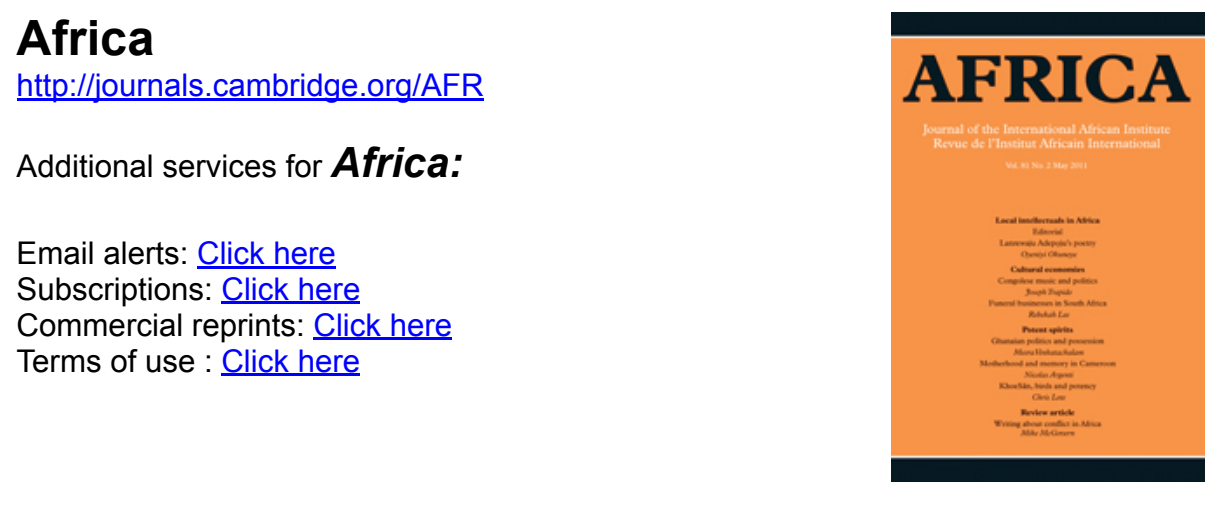

\title{
THINGS OF THE GROUND: CHILDREN'S MEDICINE, MOTHERHOOD AND MEMORY IN THE CAMEROON GRASSFIELDS
}

Nicolas Argenti

Africa / Volume 81 / Issue 02 / May 2011, pp 269 - 294

DOI: 10.1017/S0001972011000015, Published online: 28 April 2011

Link to this article: http://journals.cambridge.org/abstract_S0001972011000015

How to cite this article:

Nicolas Argenti (2011). THINGS OF THE GROUND: CHILDREN'S MEDICINE, MOTHERHOOD AND MEMORY IN THE CAMEROON GRASSFIELDS. Africa, 81, pp 269-294 doi:10.1017/S0001972011000015

Request Permissions : $\underline{\text { Click here }}$ 


\title{
THINGS OF THE GROUND: CHILDREN'S MEDICINE, MOTHERHOOD AND MEMORY IN THE CAMEROON GRASSFIELDS
}

\author{
Nicolas Argenti
}

\author{
- Mother! I called out. \\ I could hear her crying, I could feel her chest rising painfully. \\ - Mother, don't cry! I said. Don't cry! \\ But I could not manage to hold back my tears either.... \\ My father... had taken my hand, as he did when I was still a child.... \\ - Father! \\ - I'm listening, said he. \\ - Am I really leaving? \\ - What else would you be doing? You know that you must go. \\ - Yes, I said. \\ And I began to cry.
}

Camara Laye (1976: 159, my translation)

\section{FAMILY TIES AND SEPARATION IN THE GRASSFIELDS}

The chiefdoms of the Grassfields of Cameroon - a hinterland region bordering Nigeria and composed of polities differentiated by their own languages, lineages and ruling families, but related to one another as a cultural ecumenae distinct from neighbouring regions - harbour a paradox in their kinship systems; a tension at the heart of the affective life of the family and the psychic world of the child. As elsewhere in West Africa, the mother is revered as a figure of protection and nurture for her children, and the mother-child bond is sacrosanct. And yet her caring role is everywhere threatened: over the past four centuries and right up to the 1930 s-in other words, within living memory-children were regularly abducted into slavery, sometimes with the tacit consent or even the connivance of their parents (Argenti 2007), and still today many mothers send one or more of their children into foster care from a young age. In many cases, contemporary fosterage arrangements consign children to harsh conditions that they endure for protracted periods of time before returning home.

Enslavement was conducted in the eighteenth century partly by means of raiding by groups of mounted slave raiders serving vassals of the emirates of

\footnotetext{
NiCOLAS ARGENTI has conducted research in the Cameroon Grassfields since 1991. His work focuses on childhood, youth, performance, political violence, time and social memory. He is the author of The Intestines of the State: youth, violence and belated histories in the Cameroon Grassfields (University of Chicago Press, 2007), and co-editor with Katharina Schramm of Remembering Violence: anthropological perspectives on intergenerational transmission (Berghahn, 2010). He teaches anthropology at Brunel University. Email: Nicolas.argenti@brunel.ac.uk
}

(C) International African Institute 2011 
Adamawa, Muri and Bauchi to the north of the Grassfields, and partly through a southern route leading to the Atlantic trading ports of the Gold Coast (Argenti 2007; Austen 1995; Austen and Derrick 1999; Awasom 1984; Chilver 1961; 1964; Chilver and Kaberry 1963; 1968; Fardon 1988: 86-9; Nkwi and Warnier 1982: 85; Kaberry and Chilver 1961; van Slageren 1972: 74ff.; Warnier 1975: Chapter 3 and 384-5; 1985: 127). ${ }^{1}$ Even after the ending of the transatlantic slave trade, internal demand for slaves continued to fuel the sale and abduction of children and adolescents. By the nineteenth century, the trade in slaves fed a regional market within the Grassfields, ${ }^{2}$ and the largest Grassfields chiefdoms staged full-scale annual military campaigns for their recruitment from neighbouring peoples (Warnier 1995: 257-8; 2006; Tardits 1980: 800-17). ${ }^{3}$ By and large, however, the raiding typical of the eighteenth century gave way in the nineteenth to a more insidious process of depopulation: the local abduction of children for sale by their own elders (Warnier 1985: 138, 271; 1995: 263-4; cf. Chilver 1961; 1964; Chilver and Kaberry 1965; Masquelier 1978: 62). Children-especially those who were residing with affinal kin outside their natal villages as foster children or babysitters - presented easy prey for dealers or opportunists who sold them on to traders, who would in turn resell them (Warnier 1995; Argenti 2007: 33-56). As Nwokeji and Eltis (2002) have demonstrated, when we speak of the abduction of people into slavery in the Grassfields, we are speaking in the vast majority of cases of the abduction of children-abductions that continued into the 1930s. ${ }^{4}$

While internal slavery persisted within the Grassfields in the German colonial period, it met competition from new sources of demand for labour. The colonial administration and the German trading firms recruited-often coercively and through the same channels as the slave trade had operated - tens of thousands of men, women and children for porterage, while the industrial plantations set up on the coast brought in labour from the hinterland, again in direct continuity with the supply chain of slaves for the transatlantic trade (Rudin 1931). ${ }^{5}$ Rather than making the life of the child safer and strengthening the family unit, then, the German colonial period placed new strains on security and social cohesion in the Grassfields. Today, fifty years after independence, the need for Western-style

\footnotetext{
${ }^{1}$ In the Atlantic trading ports of the Gold Coast, 'Bayon' slaves, as those captured in the Grassfields were known, were especially valued for their obedience, honesty and hard work, and the evidence suggests they were traded in large numbers over centuries (Argenti 2007: 52-3; Hutchinson 1967: 322; Hutter 1902: 260; Koelle 1854; Warnier 1995: 253; Wirz 1973a; 1973b).

${ }^{2}$ The regional market included the Bamileke chiefdoms of the southern Grassfields, middlemen in the trade who sold many of their captives to the coastal Duala (Brain 1972: 13; Austen 1983; 1995; Austen and Derrick 1999; van Slageren 1972: 78).

${ }^{3}$ In the expanding conquest states of the region, human sacrifice was practised up to German colonial intervention in the late 1890s and represented a major factor in driving the continued demand for victims, many of them children (Chem-Langhes and Fomin 1995: 198, 199; Chilver 1963: 102-3; Esser 1898 in Chilver and Röschenthaler 2001: 74, 78; Chilver and Kaberry 1963: 29; Njoya 1995: 232; Rudin 1931: 299).

${ }^{4}$ As late as 1927 a court case arose involving the enslavement of a young Oku boy by the name of Mba and his sale into slavery in the neighbouring chiefdom of Nso' (Buea Archives 1927). Another case two years later concerned a young girl from the chiefdom of Age abducted from her father's house (Buea Archives 1929; see Argenti 2010: 239, fn 25 for details).

${ }^{5} \mathrm{~A}$ colonial decree of 1908 specifically stipulated that carriers had to be 'grown people, capable of doing the work' (Kolonial-Gesetzgebung XII: 67 and Kolonialblatt 1908: 512-13, in Rudin 1931: 331).
} 
education and medical care-often considered the hallmarks of successful development-coupled with aspirations of access to the urban economy puts pressure on parents to send their children away from home to live a harsh and servile existence as domestic servants for salaried urban elites (Argenti 2010). While in the ideology of Grassfields kinship the mother is still the paramount figure of attachment, fidelity and protection, then, her devotion to her children continues to be frustrated by the necessity of entrusting them to the care of others, often far away from home, and with people little known to her.

Slavery is seldom spoken of explicitly in the Grassfields, and more seldom still is it acknowledged that children were often taken from their parents. ${ }^{6}$ During the early stages of my doctoral research in Oku, which took place over a two-year period from 1992 to 1994, I investigated the medicinal rites performed for infants and young children in the chiefdom. I never wrote up this material, and had simply conceptualized the rites as a form of apotropaic medicine designed to protect newborn children from illness - which is the explicit purpose of the rites. Returning to Oku in 2005 for further research focusing on child fosterage, however, and having just finished a monograph on memories of slavery in the Grassfields (Argenti 2007), I began to rethink the rites of children's medicinal care in the light of parents' memories of slavery and experiences of fosterage, and to see in the rites a sort of double-fond of the type found in a smuggler's suitcase, wherein an apparently empty space conceals a second compartment hidden beneath a false base. In this article, I try to present the whole case of children's medicine, in which, as with the smuggler's case, the visible contents of the first compartment may be quite different in nature from the contraband concealed in the second.

From a synchronic, ahistorical perspective one can interpret the medicinal performances in a Turnerian manner as rites of passage, or life-crisis rituals. From the point of view of this first compartment, the tensions inherent in the mother's role come into focus as the temporary liminality into which mother and child are cast by childbirth, and the rites appear successfully to resolve these tensions. From a diachronic perspective that interprets the rites as practices of social memory, however, they appear not to focus on the moment of childbirth per se, but on the problematic nature of the mother-child bond over the entirety of its existence, and indeed through the longue durée of the chiefdom itself seen as an intergenerational succession of mother-child relationships. From the point of view of this silent, unvoiced but unforgotten body of social memory, then, the rites of children's medicine prefigure the separation that has yet to come of the mother from her children, while silently remembering such separations over countless generations past.

In order to demonstrate this argument more fully, I first present a factual account of the rites of children's medicine. In the following section, I go on to

\footnotetext{
${ }^{6}$ As Rosalind Shaw (2002: 1-2) has noted, this discursive silence is the norm throughout Africa, and challenges historians and anthropologists of slavery to elaborate new research methodologies. Studies by Rosalind Shaw, Peter Geschiere (1997), Eric de Rosny (1981) and Jean-Pierre Warnier (2007) on ritual, myth and witcheraft as forms of embodied or social remembering of slavery mark a notable step in this direction.
} 
present a sequential exegesis of the ritual activities before finally returning to the argument in its broadest terms.

\section{CHILDREN'S MEDICINE: A PRÉCIS}

There are three distinct though related rites performed for children in Oku, collectively known as 'children's medicine' ( $k \partial f u$ obwan). The first rite is referred

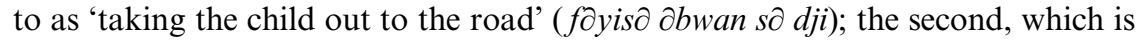
often performed immediately after the first, is called 'the child's pot' ( $\partial b s i$ - $\partial b w a n)$;

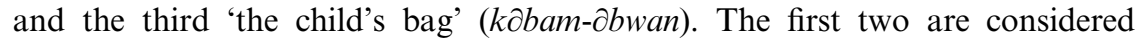
essential for all children and are consequently performed the most often, while the third is only considered necessary for children who are thought to be exceptionally bright. Such 'sharp' (tof $\partial$ ) children, as they are known, are viewed with some ambivalence as gifted but of uncertain allegiance and unpredictable character, and they are thought to be likely to be harmed by the envious, who can cause them to return to the 'world of ghosts' (ilak nkfosays $\partial$ ) from which they have only recently emerged (Argenti 2001). Evidence of unusually strong or precocious intelligence is therefore seen as an illness in a very young child, and

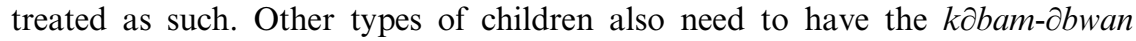
ceremony performed for them. These include twins, those born immediately after twins to the same mother, and children diagnosed from certain signs at birth - such as clenched fists, breach birth, or with the umbilical cord crossing the

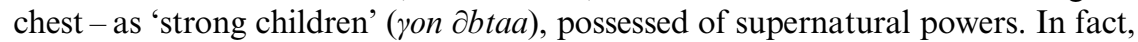
'sharp children' are considered a subcategory of 'strong children'. Below I give descriptions of each rite, several instances of which I witnessed and recorded in 1992 and 1993.

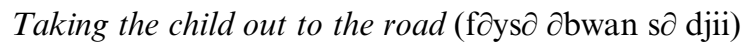

Following the sacrifice of a fowl by suffocation, the formal removal of the cloistered mother and child from the house is performed. The healer leads, holding his spear by the tip of the handle. The mother is made to hold the blade in her right hand and the baby under her left arm. The healer makes a prayer in the form of questions that she answers on her way over the lintel. He asks her three times in a row, 'Will you come out?', and each time she answers 'No'. He then asks her, 'How many times?' She answers, 'Three times', and steps over the lintel.

The healer then leads her into the courtyard and digs a small hole in the earth with the point of his spear. He pours palm wine into the hole he has just made and kneads the wet earth, feeding a small quantity of the mud to the child. The healer, the mother, the infant and the father, along with the healer's helpers, then pass behind the compound to a streambed. Two holes are dug into the soil, leaves prepared with medicine are placed in them, and they are filled with water. A stalk of elephant grass is tied to the healer's spear and the two are planted at an acute angle over the two holes so as to make an arch over them. The healer then makes another prayer, intermittently producing a soft, eerie sound by blowing a small horn and shaking his rattle. When he comes back to the place, he does so emphasizing his steps, stamping each one hard, and the others join in, stamping to his rhythm. After the lonely sound of the calls to the gods, the mood becomes 


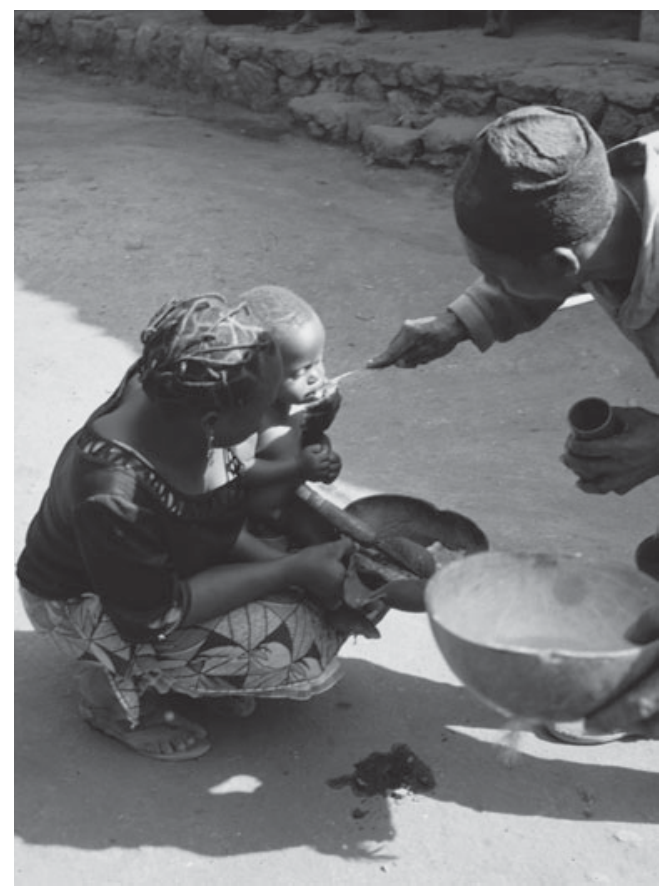

FIGURE 1 The healer Joseph Modjno pours palm wine into the hole he has just made in the courtyard and kneads the wet earth, feeding a small quantity of the mud to the child

jovial and joking again, but the stamping recalls the tfin iscy dance performed to pack the earth over a corpse (see Argenti 2007: 198-204).

The mother and child are washed, following which the healer throws two flower heads into the two holes repeatedly, performing divination according to how they float. The child's mother is then made to bury the leaf sponge in two handfuls in each of the holes, inserting them behind her back as all look away. Following this, the healer covers the holes with earth, and the mother dismantles the spear and elephant grass arch and throws the latter into the coffee bushes behind her back. The healer finally rubs all present on the forehead with camwood, and each drinks wine from his cup and licks medicine that is given out onto the left hand. ${ }^{7}$

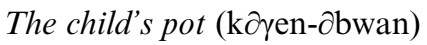

The rite, in the course of which the child's medicine is prepared, is also known as the 'god of the child' (feyin-2bwan). ${ }^{8}$ The first step consists in preparing a

\footnotetext{
${ }^{7}$ See Yufanyi (1976: 120-3); Maynard (2004: 163).

${ }^{8}$ It used to be the practice to use a clay pot from the pottery-producing centre of Babessi. The type used was an ordinary cooking pot known in Oku as an $\partial b s i$, after its place of origin, and in Babessi itself as a ntuo mba. (See Argenti 1999: 18, 36; Forni 2001). At that time the rite was accordingly known in Oku as the 'child's pot'- $\partial b s i \partial b w a n$.
} 
medicinal pot for the child. The healer plucks wing feathers from a live fowl. A medicinal concoction with earth from the floor of the house is rubbed in a circular form onto the calabash and a white chalk or kaolin-based medicine - also dug from the earth - is rubbed around it in a circle. The same medicine is applied to the back of the calabash but in three stripes, the earth-based one in the middle, flanked on either side by the chalk one. These are known as the 'eyes of the

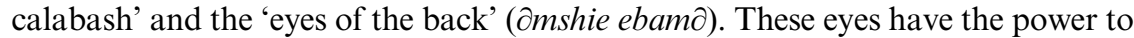
detect and kill witches intending to harm the child of the pot. The healer applies the same medicine in a striped pattern to a long-necked calabash. He then instructs the mother as to which grasses go into the medicines so that she will be able to prepare it herself on future occasions: at any new moon when the child is showing signs of illness.

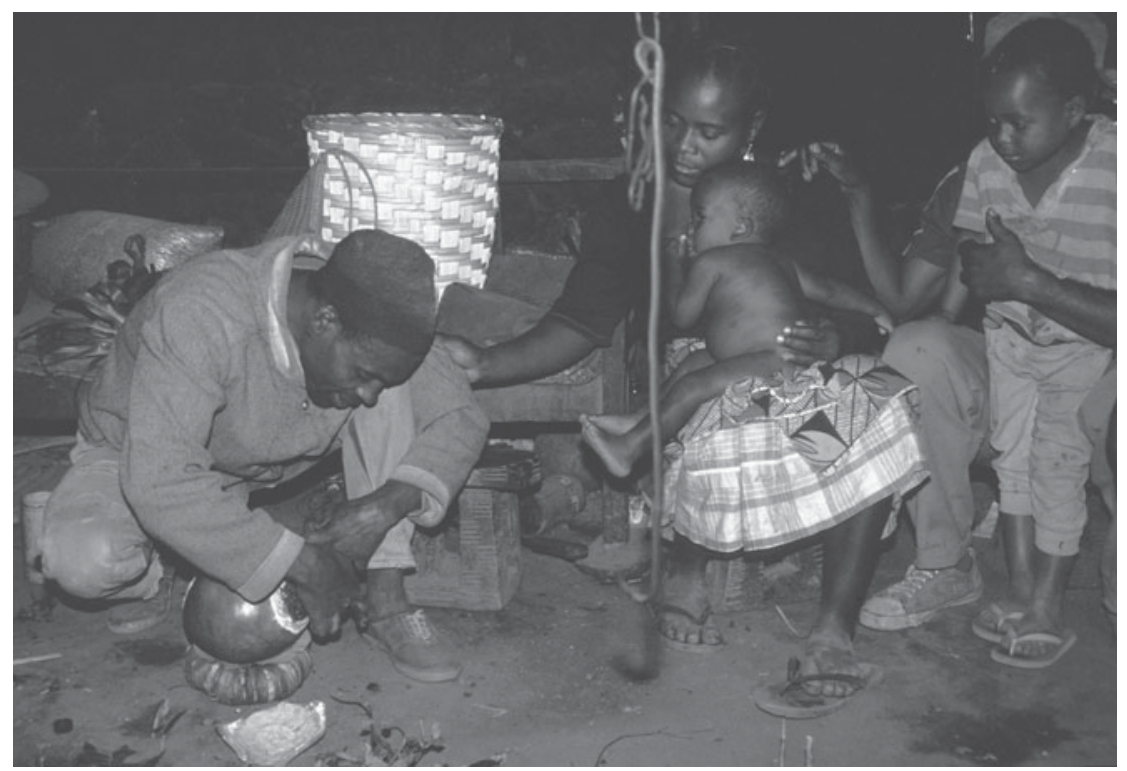

FIGURE 2 Making the koyen - Earth from the floor of the house is rubbed onto the calabash and a white chalk or kaolin-based medicine is rubbed around it in a circle

The fowl is killed bloodlessly, cooked and butchered. Another live fowl is brought to the healer, who plucks down-feathers from it and sticks them onto the 'eyes' of the calabash. The mother and child are made to stick some on in turn. The healer then sticks incense onto the ends of a flat stick. This is known as the 'knife of the calabash'. The name for knife, fofiar', is a diminutive of fiar', a cutlass. Cutlasses - used for clearing bush and in warfare - are associated with men, who always wear ceremonial versions of them for military society meetings. The smaller fofiar', in contrast, is used primarily in cooking, and associated with women. As I describe below, a version of the fofiar' - the fiar' dbvii or 'woman's cutlass' - used by women in planting corn is central to the rituals of children's medicine. The 'knife of the calabash' is placed across the top of the calabash. 
The healer pours wine on the doorstep, praying as he does so, then adds more to the calabash. The healer then throws little balls of a ritual mixture of cocoyam, palm oil and ground pumpkin seeds known as njimte into all four corners of the room, onto the ground near the calabashes and into the fire. At this stage, the fiar' $k \partial y e n$ is lit. The healer then paints stripes onto the door lintel; three sets of three: these are known as the ciphers of the calabash (eniar' koyen). Two snail shells are then placed in the calabash and 'read' by the healer according to how they float there. The mother, the child and others present then come to pour wine into the calabash and drink from it.

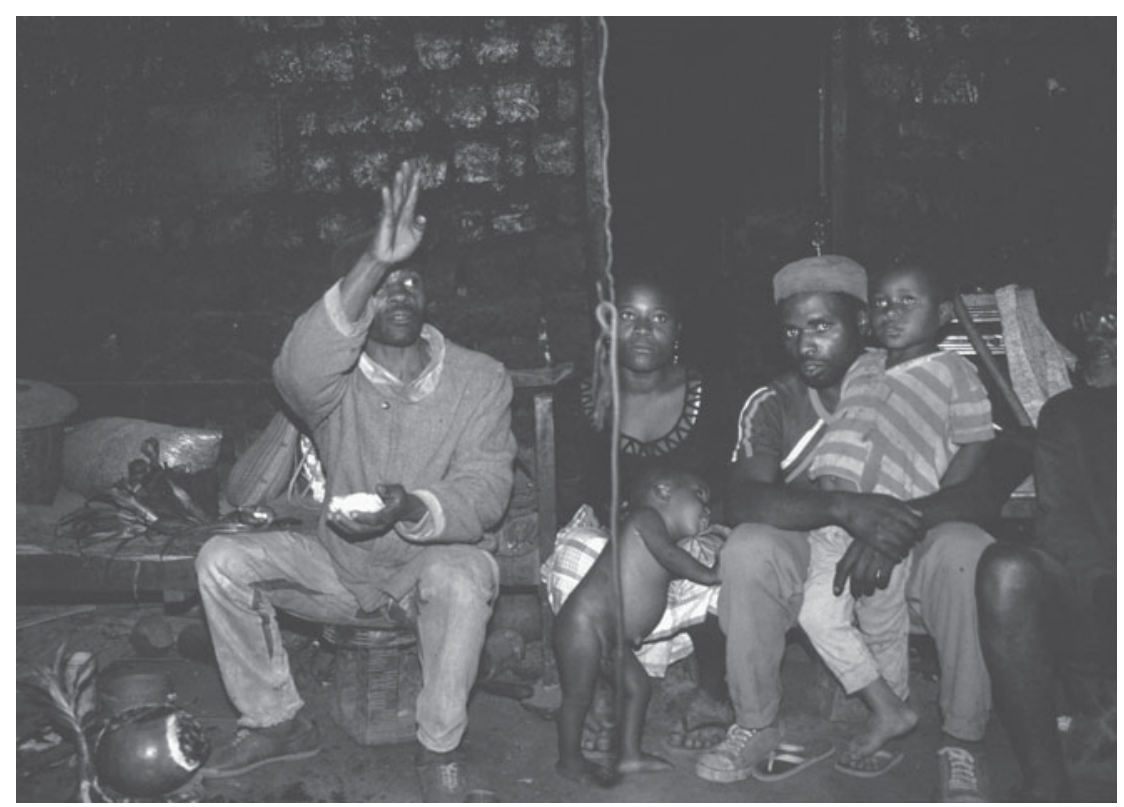

FIGURE 3 The healer throws little balls of njimte into all four corners of the room, onto the ground near the calabashes and into the fire

The party set off for the road, where an arch made out of a stalk of elephant grass tied to the healer's spear is set up over the roadside ditch or stream. A woman's planting knife (fiar' obvii) with a lump of incense atop its handle is planted in the water under the arch. As it burns in the water the healer swings the child around the knife handle. The healer recites an invocation as he does this and then, he washes the child and the mother in the stream. ${ }^{9}$ The child and the mother go through the same washing process over two small divination holes that have been dug in the ground on the edge of the compound. The planting knife and

\footnotetext{
${ }^{9}$ The prayer is the following:

'I beg God the Creator to assist this child I am treating so that s/he heals. Wash the sickness from him/her and send it into these tofungele-holes'.
} 
a locally smithed hoe are placed under the spear and elephant stalk arch, between the two holes. The healer utters a prayer and blows the horn again at this point. The extremities of the live fowl (wings, feet and beak) are passed across the water in the holes, then across the lips of the mother and child. The healer performs divination with the two flower buds again. While all present hold the assistant's arm, he kills the fowl bloodlessly by compressing its chest against the ground. Down-feathers are then plucked from it and put on the place along with $\eta k \varepsilon \eta$ leaves (Dracaena sp.). The healer and then the others sprinkle camwood on the place.

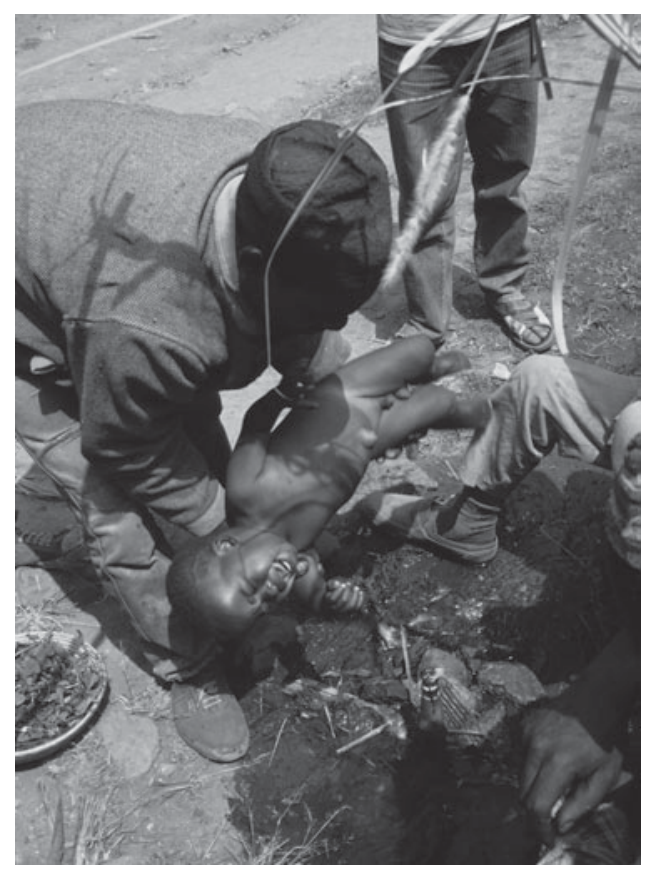

FIGURE 4 A woman's planting knife with a lump of incense atop its handle is planted in the water under the arch. As it burns in the water the healer swings the child around the knife handle

The mother is then made to dismantle the arch, throw the elephant stalks behind her, and throw the spear onto the path leading to the courtyard. Depending on the position of the spear as it lands, the healer makes certain pronouncements regarding the mother and child. All the participants then return to the house dancing in a line. They enter the house and dance in a ring around the hearth; the healer and his assistant(s) followed by the mother and child. The participants sing a song of mourning for a deceased child as they dance. The 'song of the gods' (ndjay mjin) they sing goes as follows:

Bereaved father, what will your [deceased] child give to these people [the child's mourners] that they may eat, rise up and dance? 
Who is watching your corn by the water's edge now that the river has flooded and taken your child? ${ }^{10}$

As in the previous rite, the dance evokes a burial. After the dance, the child or infant is brought to the calabashes and washed with the $\eta k \varepsilon y$ leaves in the calabash. The healer shakes the rattle with the $\eta k \varepsilon \eta$ leaves in hand and blows in the child's ears (to protect him from deafness). The child is made to drink from both snail shells, which are then rubbed round his head and down the sides of his body. The healer then hands palm oil-based medicine to the mother for her to rub on the child. He then approaches the child stealthily and cries out loudly three times. Following this, he picks the child up and swings him three times over the fire, then toward the door. As he is doing so he exclaims:

The child is falling into the fire!

The child is falling into the fire!

See the mask coming!

See the car coming!

The healer then rubs all present with medicine. He then gives the mother the medicine in between two leaves that she takes outside with the child. The rest of the medicine is passed around for all to eat after the fowl. The healer then uses a $\eta k \varepsilon \eta$ plant dipped in medicine to asperge everyone present and the assistant rubs medicine on all foreheads.

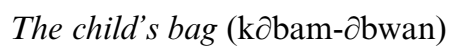

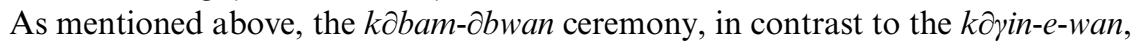
is only performed for 'strong' children. The healer begins by sewing medicine into

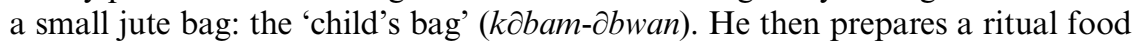
(njimte). He feeds some ingredients from it to the child in his left then his right hand. The fowl is then fed some by the father while the healer prays, throwing bits of the njimte out of the door then into the four corners of the house. The four corners of the house represent four gods in Oku: Feyin Kobur', Feyin obkwe, Feyin Fakzbun, Feyin Mbom. The njimte that is thrown out of the door is for Mbom, the Creator. Some of the njimte is finally thrown into the fire at the centre of the room. It is intended to harm any person intending to spoil the ceremony or to hurt the child in later life. The healer then gives the rest of the njimte to the mother, who feeds the child with it. Both the fowls (one male, one female) are then made to ingest some of the medicine. One of these fowls will be killed, cooked and eaten at the end of the ceremony, while the other will be given to the mother along with the medicine bag. This fowl is significant to the family for the rest of the child's life. No person can take the fowl or any of its offspring without permission from the child. If the fowl dies, a new one must be acquired and rubbed with the medicine again. The healer then sprinkles the child's body with medicated water and rubs him with one of the fowls. This washing is seen as a treatment to cure the child of its 'illness'.

The child is then given small change mixed with cowries (also once currency). The healer then gives the child three $\eta k \varepsilon y$ leaves to hold, which he is made to hand

\footnotetext{
${ }^{10}$ For versions of this song sung at a burial, see Argenti (2007: 232-3) and Njakoi John Bah (2000: 50).
} 
to his mother one by one. This is the introduction to the stage known as tomo abwan, in which each person in the room must make gifts to the child by taking some oil and salt from the mother's hand and eating it twice, then giving it to the child twice to eat, then twice to the mother. Each person follows this action by taking two $y k \varepsilon \eta$ leaves from the healer and handing them to the child. The person then 'begs for' one of the leaves from the child and gives him or her some small change in return. It is said that the tomo dbwan is performed so that the child may be 'satisfied' with gifts in order to prevent their using their power to harm others later on in life. The mother is then made to hold the healer's hand as he packs the oil, salt, money, cowries and medicines (including the sewn bundle and a stone from the shore of the sacred crater lake Mawes) into the medicinal bag.

\section{EATING THE GROUND: AN EXEGESIS OF CHILDREN'S MEDICINE}

Taking the child out to the road (foys $\partial$ obwan s $\partial \mathrm{dji}$ )

The passage out of the house with the mother and child holding the tip of the healer's spear marks the end of a period of seclusion or internment for the mother and child after birth. The healer's use of a spear reveals what it means to give birth: to bring the wild and the foreign into the compound courtyard. Many married women in $\mathrm{Oku}$ and the other kingdoms of the Grassfields originate from outside the kingdom. ${ }^{11}$ Even before they bear children, therefore, they are seen to be breaching the boundaries of the polity and introducing to it a foreign element. Their children, represented as emerging from the unbounded realm of the ancestors, are equally suspected of having allegiances to them and their foreign lineages. The rite thus highlights the liminal status of the woman and child alike as undomesticated people, not only foreign but other-worldly in origin.

The next rite to be performed, feeding the earth of the compound courtyard to the child-again with the spear-directly addresses this problem. One healer explained the significance of eating earth from the courtyard in the following manner:

It is Oku ground. It is law ${ }^{12}$ that any child born here [in Oku] must eat the ground here. When he comes out of Oku, it will be a strong man who harms him.

Eating the ground of $\mathrm{Oku}$ is said to be as harmful to foreigners as it is protective to Oku people. Belligerents on a disputed boundary of the chiefdom, for example, have been challenged to eat the ground that they claim. The ingestion of the ground of the courtyard and its representation in terms of an inoculation against later ordeals therefore plays a strong ideological role in demarcating the space of $\mathrm{Oku}$ as a place that is territorially fixed and impermeable. ${ }^{13}$ In doing so, the rite makes of the compound a metonym of the kingdom, and makes of the kingdom a large-scale model of the compound. Again, the child is not fed with a

\footnotetext{
${ }^{11}$ Robert Brain underscores the foreign origin of women in the Bangwa chiefdom when he says that 'It is part of Bangwa dogma that a person's female ancestress, traced matrilineally, was a slave, bought in a Grassfields market' (1972: 14). Warnier (1975: 375) estimates that in the nineteenth century between 20 and 55 per cent of married women in any one chiefdom came from elsewhere in the Grassfields.

${ }^{12}$ Literally a 'thing of the ground' ( $k \partial n \partial \partial$ ntie).

${ }^{13}$ For the Bamileke practice, cf. Feldman-Savelsberg et al. (2005: 14).
} 
spoon or by hand, but with the tip of the spear. While this gesture evokes the association of the ordeal of eating the ground with boundary disputes, warfare and violence - the word eyoy means both 'spear' and 'war' - it also highlights the continuing association of the child with the realm of the forest, as a nemoral creature who has yet to be domesticated, or a foreigner who has yet to be naturalized.

The spear, used like the cutlass against hostile aliens in war, is additionally a weapon that the hunter takes with him into the forest, making of it a natural ritual instrument for the healer who must also venture into other worlds to complete the journey of the newly born and repair the breach caused by its arrival. In the next step of the ritual, the spear once again serves to bridge between worlds, this time quite literally as one side of the arch. The arch, formed by the spear on one side which is attached to a stalk of elephant grass on the other and set in the ground at a 45 degree angle, is erected as a passage to the other world, in this case to the realm of subterranean spirits. The entrance to this chthonian world is demarcated by the two holes dug under the arch, which serve as a means of communication with the spirits and the ancestors. They will later serve the healer to ask the spirits direct questions by throwing flowers into the medicinal water poured into them.

When the healer blows his horn and shakes his rattle he produces the acoustic dimension of this form of cross-world communication, calling forth the "thing [of

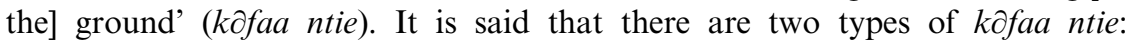
something described as a mole, ${ }^{14}$ and something resembling a short subterranean snake..$^{15}$ When the healer digs the holes and places the medicinal leaves and water inside them, he is calling these redoubtable creatures to the surface. The healer's prayer makes his call explicit:

I am blowing [this horn] for you, $\partial b w e n$ [the ritual name of the mole], Hold up your head, walk quickly, quickly,

Those who are ill with something else that has caught them [with a disease caused by witchcraft],

You will come walking and clean it [break it open] from your skin, all shall see.

As you come, do not wander.

You who passes through the stones, crosses rivers, passes under trees,

There is no place that you have found hard to cross. ${ }^{16}$

\footnotetext{
${ }^{14}$ Most likely the Nigerian mole rat (Cryptomys foxi), which has been recorded in grasslands, rocky areas, riverine forest and along streams in Nigeria and Cameroon (Maree and Faulkes 2008). The description of the animal's varied habitat provides a remarkable fit with the last lines of the healer's eulogy: 'You who passes through the stones, crosses rivers, passes under trees, There is no place that you have found hard to cross'.

${ }^{15}$ Perhaps the West African blind snake, Leptotyphlops debilis, which burrows in the ground and resembles a large black worm.

${ }^{16}$ Consider the remarkably similar prayer made by the Ndembu, $2,500 \mathrm{~km}$ to the South of Oku in north-western Zambia, to the giant rat or ant-bear who lives in a subterranean burrow:
}

Giant rat (ant-bear), if you are the one who kills children, now give the woman back her fertility, may she raise children well.

This prayer is made to the rat - known as 'the witch' and explicitly associated with the world of the dead - as part of the fertility rites of isoma aimed at curing infertility. During the rite a tunnel 
As part of their internment following the birth of a child, mothers and their newborn children are meant to remain within close range of their compounds, and to avoid crossing streams. The passage to the stream at this point serves to end this prohibition. As natural boundaries, streams evoke the borders of the kingdom, and they are seen as the natural crossing points for witches attempting to enter human settlements. A great deal of ritual attention is therefore devoted to protecting bridges and riverbanks from their malefic effects. Such precautions embody memories of the time of the slave trade, when those who were taken beyond a certain boundary - usually marked by a river-could no longer be ransomed or bought back by their kin. Moreover, rivers are not only boundaries and landmarks that symbolize journeys in their crossings, but they are often the very means by which journeys are made. As such, they are taken up in this rite as a point of passage into the other world; the world of ghosts. ${ }^{17}$ If the mole is said to like the water, it is in part because its ability to pass between worlds by living above and below ground makes it metaphorically amphibious. If crossing rivers implies crossing between worlds and highlights anxieties regarding the permeability of the worlds, then denying the mother and child permission to cross streams would appear to serve as a means of shoring up the threatened boundary and anchoring the liminal neonate and its foreign mother firmly in this world.

Mothers share in the ambiguous place occupied by children not only because they venture into the other world to obtain them, nor because they are often foreign themselves: their exposure to the kəfaa ntie as they work in the fields also serves to reinforce their liminal status. While highly respected not only as mothers but also as producers of food and of the nurturance that it symbolizes, women are also endangered by the possibility of killing a mole as they farm. If a woman accidentally cuts a mole with her hoe or planting knife-objects which feature prominently in these rites - while farming, she or her child will fall ill unless they have performed the fouys $\partial$ obwan rite. Farming is thus anything but mundane in Oku. In the act of turning over the earth with her hoe, breaking its surface and exposing its interior, as in the act of stabbing the ground with her planting knife to make the clefts in which to plant her seeds, a woman effectively crosses worlds every working day. Furthermore, it is only by crossing worlds that she can produce food, reaping a harvest by extracting it from the other world of which she has breached the boundary - effectively taking food from the gods just as she does children in the act of giving birth. Producing food and producing children are thus both acts of nurture and reproduction that simultaneously endanger the polity by breaching its boundaries and indebting it to vengeful spirits.

The prayer the healer makes is highly respectful of the mole, which it portrays as a sacred animal, but a healer once confided to me that he does not for all that see the mole as a benign force. For him, the process of feeding the mole is a subtle form of entrapment. The moment at which the mole is judged by the healer to

is dug joining up with the rat's burrow. The woman is made to pass from the entrance hole, associated with life, through the tunnel into the world of the rat, the realm of death, then back into 'life' again (Turner 1969: 10-43).

${ }^{17}$ Rosalind Shaw (2002) has analysed Ben Okri's visionary references to rivers in his 1991 novel The Famished Road. Cf. Argenti (2007). 
have 'eaten' the medicines offered to it is known as 'catching the mole'. Only by catching the mole can the child stay safe and well. Moreover, the mole must be shown to the child, so that s/he may 'see what is harming him/her'. Revealing it reduces the power of the thing to do harm, hence line 3 of the prayer promising that all will see the mole and its diseases. The healer portrayed the mole as angry and vindictive: 'It says in anger: your mother killed me, I will kill [her] child.' The healer's prayers in these rites call upon the gods to 'turn away the bad dead, turn away the bad spirits' from the child, and to protect him or her from foreigners. Disease thus results from the failure to protect one's child from the permeability of the boundaries separating one world from another, the failure to encapsulate one's child unambiguously inside the polity, and the inevitable debts incurred in a zero-sum universe. ${ }^{18}$

\section{The child's calabash ( $\mathrm{k} \partial \mathrm{yen}-\partial \mathrm{bwan})$}

Earth is once again a central element of this rite, taken this time from the floor of the house and used in the 'eye' of the pot/calabash. Knives and blades also recur: first in the form of the 'knife of the pot'; then in the use of the healer's spear to make an arch - this time over a stream; next in the woman's planting knife that is stuck in the stream bed; and finally when the mother throws the healer's spear towards the compound from the road. In the foys $\partial \partial b$ wan rite, she had been led out of the house by the tip of the spear like a hunted animal; now she returns to her compound by means of this active, virile and masculine act, in the role of the hunter or the warrior-her symbolic masculinity marking her conversion from a stranger into a citizen, from a liminal being into a full member of the community. ${ }^{19}$ Evans-Pritchard (1956: 232), in his analysis of spear symbolism among the Nuer, notes that an explicit level of symbolism clear to all is doubled by a deeper level. In this case, we may say likewise that the woman's conversion from hunted to hunter accommodates two levels of meaning. The overt level of signification positions the woman squarely within the parameters of rites of passage, in the course of which the new mother who was rendered liminal by childbirth is reinstated into the realm of full humanity and participation in the community. At a deeper level, however, this apparent resolution is questioned or traduced by the symbolic positioning of the armed woman as a hunter in the realm of the spirits, from which she appropriates her children. This second level of significance does not return the mother to the realm of the living, but rather emphasizes her ambiguous role as one who breaches the boundaries separating the realms of the living and the dead, adopting in the spirit realm the masculine role of the hunter seeking human beings for the realm of the living.

And just as the child was shown the mole in the $f \partial y \partial \partial \partial b w a n$, it is now shown the woman's planting knife in the stream. If the mole is a cause of illness because it has been killed by the child's mother, the knife is the means by which it was

\footnotetext{
${ }^{18}$ In game theory and economics, zero-sum games or transactions are those in which one person's gain produces an equal loss to the other(s) involved in the transaction. In a zero-sum conception of the economic environment, there is no such thing as win-win, only win-lose.

${ }^{19}$ In Oku as amongst the Nuer (Evans-Pritchard 1956: 233-6), the right hand is referred to as the 'spear hand/arm' (abkoy eyon), and in Oku the gendered nature of this opposition is

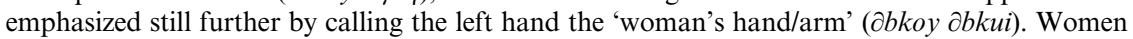
are thus categorically opposed to spears.
} 
killed, and thus equally a cause of illness to it. The dangers posed by the planting knife and its ambiguous status as an object that produces food by breaching the boundary between worlds are further illustrated by the burning of incense on the handle of the knife. The use of incense recalls not birth celebrations, but burial ceremonies, where it is applied to the tops of the posts of the bier. In the burial ceremony, the incense is said to call to the ancestors and to ensure the safe passage of the deceased to the other world. In this case, it completes a passage in the other direction.

Initiations into secret societies in Oku involve being shown the secret objects possessed by the society. These farming implements - breaking open the earth and occasionally killing the 'beings of the ground' as they did so - were a danger to the unborn child as a non-initiate in the subterranean world of the dead. But birth is the exemplar of all initiations, and it is treated as such in Oku, where the newborn becomes a neophyte who must have the secret things of the living revealed to it in order that they may no longer harm him or her.

While on the face of it celebratory, the song of the gods is highly ambivalent. In the first place, continuing the association of birth, infancy and motherhood with death, it is a type of song that is normally sung for a burial and it consists of macabre verses regarding not the protection, but the death of children (cf. Bah 2000). In this version of the song, while the first two lines refer sinisterly to stamping the earth over the bodies of small children as they are being buried, the next two ask rhetorically who is watching over the mother's fields now that her children have been swept away by the river. When sung on the occasion of a burial, 'songs of the gods' such as this one are straightforwardly tragic. When sung by the healer for medicinal rites, however, the song is delivered in a tonguein-cheek tone that is underscored by the curiously merry dancing that accompanies it. Lacing its humour with the threat of impending tragedy as it does, the 'song of the gods' performed for the preparation of the child's medicine is fraught with tension: while celebrating the birth of a child and marking its initiation into the world of the living, it simultaneously confronts its parents with the threat of its disappearance.

In the context of the medicinal rite for the child, the effect of the song, apparently light-hearted though it may be, is to represent the mother-who has just been depicted as a killer of moles in the fouys $\partial$ bwan ceremony-as mourning her newborn child. This feint of mourning for a living child has several levels of significance for those engaged in it. First among these is the more general tradition in Oku of deceiving Death. At obsequies, for instance, the deceased is advised just prior to their burial to tell those in the 'land of ghosts' (ilak pkfosaysa) that 'everyone here has died', and that there are no more people left to take from the land of the living (Bah 2000: 49). The dead, the $n k f o s a y s \partial$, are treated with a similar combination of obsequiousness and derision in the funeral ceremonies performed for otters. Like moles, the otters endemic to the sacred crater lake Mawes are seen to bridge between the realms of the living and the dead as they do between the realms of dry land and water-indeed, the lake is said to turn into a village every night, where the dead can be seen going about their daily lives (Argenti 2007: 35). When it is accidentally killed in a hunter's trap, an otter must therefore be mourned with all the respect that would be given to a human being on its way to the other world. However, this ceremony is in practice carried out in a perfunctory manner, with the officiate interspersing his prayers and the 
ceremonial firing of a danegun expected in human burials with wry asides, swigs of palm wine, and fits of stifled giggles. Everything happens as if the otter had to be flattered, but was not really due the respect of those who are tethered to this earth, for the otter roams in the realm of the dead and, feared and respected though it might be, it is also despised. Indeed, so well established is the notion of cheating Death that sickly children or those born after a stillbirth or a child who died in infancy are named 'Laughs at Death' ( $T f \varepsilon k$ ekwo).

Apart from the emphasis on deceiving Death, however, other more sincere factors would seem to motivate mourning for a newborn child: for one thing, in a cosmology based upon the premise of two parallel worlds, is not birth merely a death seen from the perspective of the other world? What is the birth of a child to an otter, a mole, or a ghost if not the death of one of its kin? Life in such a universe is a zero-sum game, in which each birth represents a loss, each death a gain and the reaping of each crop a theft from the point of view of those watching from the other world. If mothers are killers of moles, it is not only because they occasionally fell the animals as they farm, but more fundamentally because in farming they pilfer from the other world, while in giving birth they do not conjure life out of the void, but rather wrest souls (keyus) from the land of spirits, inevitably incurring debts that will one day have to be repaid. The 'illness' of the 'strong child' is precisely that it has failed to forget its other-world origins.

\section{The child's calabash (k $\partial \mathrm{bam}-\partial \mathrm{bwan})$}

The constrictions imposed by a zero-sum universe are nowhere more in evidence than with twins or so-called 'single twins' - children diagnosed as having left a twin sibling in the other world as they passed into the world of the living. ${ }^{20}$ Such 'strong children' bring to the fore within one child all of the tensions of managing the precarious balance between the worlds that are evident in society at large. Twins and 'single twins' embody the zero-sum universe in a microcosm, evoking its tensions within the duality of their own being. When they are well fed and happy, their otherworld sibling is jealous and angry, biding its time to take revenge, and when the child is asleep, wasting or ill, it has joined its lonely sibling to play in the other world - perchance to stay. Single twins are therefore treated with kid gloves by their parents, ever-worried that their capricious offspring might decide to return to its beloved sibling who never tires of calling out to it from the world of the spirits.

One of the means by which children are entreated not to return to the world that they came from is by means of small gifts, and the fowl that is kept for the child in perpetuity after this rite reifies this relationship. Its status as an inalienable gift is underscored in its name: it is referred to as the tfiese fowl. An object that is

\footnotetext{
${ }^{20}$ Members of this special class of twins are known in Eblam Ebkwo as 'strong children' ( $\gamma o n$

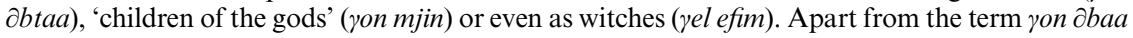
(two children), which is specifically used to denote biological twins, all of these terms can be applied to both biological or to 'single' twins (Bah 2004: 61-2; cf. Diduk 1993; 2001). See Marianne Ferme (2001: 199; 213-16) for a similar conceptualization of early childhood and single-twinship among the Mende of Sierra Leone. Single twins in Oku could also be seen as 'transcending the closure of binary oppositions, without resolving them', as Ferme says of single twins in Sierra Leone (2001: 216).
} 
tfiese has been treated medicinally in such a manner that it has acquired powers harmful to the uninitiated. ${ }^{21}$ The child's fowl thus acts as a protective amulet, warding off witches or the bad dead (nkvosay dbee) who might try to call him or her back to the world of spirits. Once again, the fowl's status as a gift to the child and a form of apotropaic medicine casts the parents of single twins - and in particular the mother - in the role of protectors and figures of nurturance to their children. Like the relationship to the mole, however, the twin's relationship to the fowl is a paradoxical one, for the fowl, being tfiese, is by definition close to the other world. The sacrifice of the second fowl, the tfiese fowl's own 'twin', in the rite illustrates this point, setting up a parallel relationship between the child and the fowl; each one with a twin in the spirit world. Single twins are suspected of blaming their parents for having removed them from that world, in which they lived happily together with their twin.

As one healer explicitly stated, the tomo dbwan ceremony of handing gifts to the child is a rite of appeasement. However, the fact that the child is made to return the gifts to its mother and to the healer complicates this explanation. In the Cameroon Grassfields as in West and Central Africa more generally, children are socialized into sharing from an early age. One of the means by which a child's older siblings and parents achieve this is by teasingly asking toddlers to part with something that they have just been given - typically food - by their carer. The gift ceremony parallels this common game. Additionally, the ceremony connects with

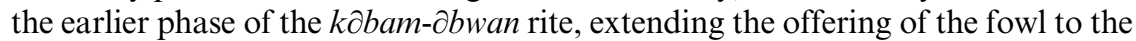
child with further offerings, this time of medicines and money. Just as offerings must be made to the mole as a representative of the underworld in the kayenabwan rite, so too in this case offerings are made to the child itself. As a spirit who has suffered the loss of a sibling in its uprooting and its passage to its new abode, it is seen to be angry with the new mother, who must placate it. Furthermore, being a spirit child, it knows the sins that the mother-killer of moles and child abductor - has committed in the other world. Ordinary children who have no sibling in the other world do not know of their spirit past. This is why they are not considered to be as likely to return to their place of origin. But because single twins know what they have lost and what their mother has done 'against the ground' their anger must be assuaged. Despite the protective theme of the ritual, the tomo wan ceremony is fraught with tension. It introduces contradictions to the ideal role of the mother as an unconditionally nurturing and protective figure and depicts the life/body (Obwun, 'skin') of the child as impermanent, fragile, and prone to incursions by external agents. ${ }^{22}$

\footnotetext{
${ }^{21}$ In one of its senses, the term refers to the altar-like constructions erected by traditional healers on the site where a theft or some other crime has taken place to house medicines designed to harm the perpetrator. The most feared of these contain a small human figure known as a monsok, which is believed to be deadly. Traditional medicines in general are considered $t f i e s e$, as are the 'things' of secret societies. Additionally, masked dancers are said to be $t$ fiese.

${ }_{22}$ As Warnier (2009) has noted for infant care in Mankon, the rites of children's medicine in Oku are closely related to everyday acts of care that the mother will repeat upon her child from then on, and which the child will internalize and repeat upon their own bodies as adults. Feeding the child, rubbing it with palm oil, giving it medicinal concoctions to drink from its pot will also be actions performed upon the child's body regularly from then on. In this way, the outer limit of the body, like the border of the compound, of the village, or of the kingdom itself, are all focused upon as sites in need of constant care, upkeep, surveillance and repair, and these concerns are
} 


\section{RITES OF PASSAGE, REALMS OF MEMORY: SLAVERY, ABDUCTION, FOSTERAGE AND MIGRANT LABOUR IN RITUALS OF CHILDCARE}

These rites depict early childhood as a subject of great tension, and children themselves as targets of struggles between local and exogenous forces - the latter represented by foreign mothers, chthonian beings, otherworld spirits and jealous twins, all of them breaching the fragile boundaries of the polity, the compound, and the child's own body, and tempting the child to leave. ${ }^{23}$ This raises the question as to what social reality prompts such tensions in the mother-child relationship? What are the materialist factors that render the territorialization or groundedness of the child within the compound and kingdom problematic? Once one asks the question in these terms, it is not hard to see that the ideal of motherly devotion and of the inviolable bond between the mother and her children is everywhere threatened in Oku, that this has been the case historically, and that it continues to be so in the present.

In the first place, as mentioned above, the imbrication of the Cameroon Grassfields into the global economy by means of the brutality of the transatlantic slave trade instituted a political economy of terror from the sixteenth century onwards in the region. Children were regularly kidnapped for sale to slave traders, while others were surreptitiously sold by their lineage elders (their classificatory fathers), their foster parents, or in extreme cases by their biological parents. Secondly, since independence the institution of fosterage - which until recently had negotiated the movement of children within the confines of the Grassfields region - has come under such pressure from the monetization of the economy that children are being sent farther afield than they ever were before, and no longer to kin but to strangers under conditions that often come to resemble forced labour. ${ }^{24}$ Where mothers once lent out their children to needy grandmothers and to childless kin within the chiefdom, they are now forced to send them to work for salaried elites in towns and cities on the promise of an education that often fails to

\footnotetext{
internalized practically by the growing child as a form of care for the self. Over time adult concerns are imperceptibly passed on to the child by means of work on the body-work first carried out by parents and healers, and later internalized by the subject, becoming a form of work upon oneself, or of political subjectivation. What it achieves is a gradual disambiguation and individualization of the child as a being that begins life by straddling worlds.

${ }^{23}$ Using Meyer and Geschiere's (1999) model of flow and closure, we would say that children have come to symbolize and serve as a locus for apprehensions regarding flow and that the rites performed upon them concretize efforts to stem the tendency of flow and to impose closure in the polity.

${ }^{24} \mathrm{I}$ have no room to describe fosterage institutions in detail in this article. For more information see Argenti (2010). Local anxieties regarding the increasing risks faced by children have focused to some extent on the national government. Traditional songs sung by Oku women at the birth of a child that I recorded in the early 1990s refer to conspiracy theories about government inoculation campaigns designed to eradicate the population. The songs are structured as choruses sung by the whole group of women present at the birth interspersed with solos by more confident, older singers. During one such song, a singer interjected the solo
}

The thing of childhood [i.e. the secret of childbirth] is so sweet Paul Biya [Cameroon's President],

The thing of childhood is so sweet Paul Biya, [And] you give children injections?

The thing of childhood is so sweet Paul Biya. 
materialize. ${ }^{25}$ Finally, as children age, adolescent boys are forced, again by the strictures of the market economy, to work as migrant labourers, often on the coastal plantations that claimed so many lives in the colonial era, while young girls also travel abroad to find work, often as prostitutes - a form of labour that since the advent of HIV/AIDS involves a similar death toll to that of colonial forced labour.

Children's medicine thus not only remembers past abductions and disappearances, but also prefigures in veiled terms the role that the mother may later come to play in leaving her children and in separating them from one another as she sends them into foster care. ${ }^{26}$ The rite of the child's bag is explicitly concerned with this problem. A 'child of the bag' (wan kJbam) - a spirit child or single twin

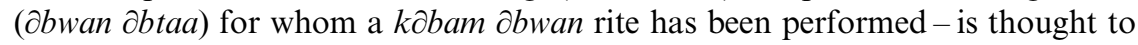
be unlikely to want to return to its parents once fostered. The child will be homesick, but not for its parents' house: it will seek to return to live with its unborn sibling. Such children are said to want to eat palm oil, to be 'seeking oil'

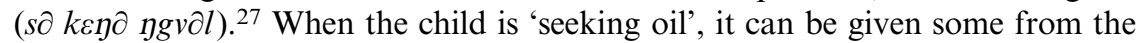
medicine bag that has been prepared for and always accompanies it. The oil is given as a form of atonement, in a repetition of the original ritual. Children's medicine also highlights the tension under which the mother-child bond is placed by the modern necessity of migrant labour, and it evokes the unspeakable memory that children were once sold by their parents in the period of the slave trade. The fact that the child is made to offer a gift of money to the mother-and in particular of cowries, the shell currency of the slave trade-silently commemorates the guilt of the mother. ${ }^{28}$

The three rites form a common vocabulary of shared ritual acts. Thus the tripartite prayer that marks the passage over the door lintel, the reversals or

See Feldman-Savelsberg et al. $(2000 ; 2005)$ for a similar rumour among the neighbouring Bamileke.

${ }^{25}$ Jean-Pierre Warnier (pers. comm. 18 Jan 2011) relates that when he was teaching at the University of Yaounde in the 1980s several of his colleagues from the Grassfields had foster children from their hometowns or villages residing with them. These 'cousins' did all of the household chores, freeing the lecturers to devote all of their time to their work. In exchange, it was understood by the children's parents that they would be put through school. In practice, while some of them attended school, there was a radical distinction between fostered children and the children of the household. Due to their domestic chores, the foster children had no time to do their homework outside of school, could only attend irregularly, and worked 12 to 15 hours a day all told. Even so, Warnier was informed, this was not a bad thing: if they never graduated from school, at least they would no longer simply be 'bush people' (cf. Bledsoe 1990 on the presumed 'civilizing' influence of fosterage among the Mende of Sierra Leone).

${ }^{26}$ It may seem an unwonted anthropomorphization to speak of rites as 'remembering'; one might expect me to say rather that they cause the participants to remember. But it is the opposite that is true: by addressing the mother-child bond obscurely - in a double-fond - the rites serve as a hiding place for unspeakable memories and their performance enables participants not to encrypt or entomb their memories. The rites, in a word, provide a means of collective forgetting, albeit one doomed to constant repetition.

${ }^{27}$ Palm oil - used both as a condiment and body-rub - is a luxury in Oku. To be badly cared for can thus be represented as lacking oil or being denied oil. One knows when a child is 'seeking oil' when it inexplicably moves objects in the house, stops speaking, is disobedient or unresponsive.

${ }^{28}$ Cowry shells belonged to a restricted, elite sphere of exchange in the past, and one of the only means to obtain them in the Grassfields was by offering slaves in exchange for them, typically children who had been abducted locally (Argenti 2007: 132-5). 
inversions of many of the procedures, which are carried out by the mother behind her back, the emphasis on the boundaries of the compound and of the bodies of the mother and child, the concern with the ground as an apparent passageway to another world - these recur in all of the rites. The rites highlight paradoxes regarding the reproductive role of the mother and the ambiguous position of the newborn child as one who arrives from the realm of the ancestors. If the child has arrived from the other world, it is at once a foreigner to the polity and a recently 'dead' being of uncertain status in the realm of the living. Likewise, as the one who forms the bridge between these worlds by means of which the child crosses from one to the other at birth, the mother has entered into close ties with the other world, and her confinement and the rites that follow-with their emphasis on passage, knives and cutting, and separation from the world beneath the surface of the ground-address her ambiguous status and return her to the world of the living and its normal social ties. Turning their gaze from a focus on the past toward one on the future, however, the rites also identify parents' fears regarding the dangers that their children will come to face, seemingly restoring the boundaries that not only birth, but also disease, departure and death breach: those of the body, of the social fabric of the compound, and of the divisions between the worlds of the living and the dead.

In other words, the child-focused rites of Oku highlight anxieties not only regarding birth and the health risks associated with early life, which we might call passagerial, but also anxieties regarding dangers that are inherent and enduring to the social fabric of Oku and to African kinship more generally: the institutions of slavery, fosterage, and migrant labour as they affected the chiefdom collectively in the past, and as they will affect the child personally in the future. In addition to the fear of child abduction in the period of slavery, parents in Oku always live with the possibility that they will someday send one or more of their children away to live in another chiefdom or in one of the provincial towns of the Grassfields, if not further afield to the capital Yaounde or the main port city of Douala. Cati Coe (2008), in a detailed and nuanced case study of Ghanaian transnational families, has demonstrated that parents feel very ambivalent about leaving their children behind as they emigrate to find work. Likewise in Oku, where parents live for protracted periods of their lives with the knowledge of the possible disappearance or exile of one or more of their children from their compounds at an early age, a tension arises between the ideal of the nurturing mother on the one hand and the institutions of fosterage and the modern necessity of migrant labour on the other. This tension is not passagerial, but protracted, both historically and in the microcosm of the family unit.

The overt discourse of the rites casts the parents, and the mother in particular, in the role of protectors. It is the parents who go to the trouble and the considerable expense of organizing the protective rites for their newborn children. They are the ones who intend to ensure that the child will be firmly grounded in the polity and protected from witches and the illnesses they cause. The rites would therefore seem to support the sacrosanct role of the mother in the kinship system. The role played by the child in this discourse is more ambiguous. As a recent arrival, it is as yet of uncertain allegiance. Many children, especially 'strong children', in this position are known as transforms or changelings ( finte) who are wont to turn themselves into chameleons and other animals in order to follow their mother to the farm by hiding in her basket. Once in the field - that place of 
the cleft earth through which they have passed - they are tempted to return to the world of their playmates rather than stay in this new and foreign place. ${ }^{29}$ While parents are nurturing and protective figures, then, neonates are mischievous; and while parents are seen to be doing everything they can to keep their children with them, children are devious, 'homesick' and wont to attempt to escape back to the world of the dead. ${ }^{30}$

The social reality, however, contradicts this discourse: children are not born with a death wish, and their high mortality rate is not due to their 'strong heads'

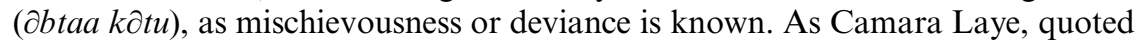
in the epigraph, has so eloquently testified in his autobiography (1976), children often want nothing more than to stay with their parents and siblings in their compound of birth. It is not typically children who decide to flee, but parents (and historically also lineage elders and the palatine elite) who send their children away. This reality is reflected in what we might call the double-fond contained within the $k \partial f u$ wan rites that stands in tension with the overt discourse of the rites. Within this double-fond, the mother does not protect the child from witches - she provokes the witches. As we saw, the rites portray the mother as the killer of moles, the 'things of the ground', and the farm implements that seem to emphasize the division of the worlds after birth are the same ones by means of which the mother pierces the amniotic envelope separating the worlds every day. In carrying out her nurturing role as a farmer and in obtaining children from the other world, she simultaneously angers the gods, and her sins will return to haunt her children. The rites reveal that the child will pay for the deeds of the mother. What the mother has done 'against the ground', as the worst sins are known, she will do again against the child - who belongs after all as much to the realm of the ground as to that of the living - by sending it into the effective exile of foster care. In portraying the biological family of the child as a new and foreign place with which it is unfamiliar and in which it is lonely and homesick, the rites prefigure the position of the foster child in its adoptive family, and simultaneously recall the erstwhile sale of children into slavery. The emphasis upon offerings to the ground in these rites are therefore acts of appeasement or of absolution for the sins of the mother, the ultimate penalty for which is the death of her children: in the words of the mole, 'you killed me, I will kill your child'.

In portraying the position of the mother as fraught with tension, the rite is indeed true to life: are not the very parents who nurture their children the same ones who will later give them away? Indeed, are not many mothers in the Grassfields also foster mothers, whose children were borne by other women?

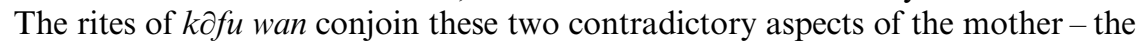
(good) mother who gives birth and who nurtures and the (bad) mother who

\footnotetext{
${ }^{29}$ Kent Maynard (2004: 94, note 20) observes that twins and 'single twins' in the Grassfields chiefdom of Kedjom are also said to transform and to have 'spirit friends' whom they meet on their mothers' farms. Maynard (2004: 89-90, 94 n. 20, 102 n. 78) further notes that fields were always planted with a central ridge known as the 'child's bed'. This ridge was higher than the others, and an altar was constructed upon it in which the compound head could make offerings on behalf of his children.

${ }^{30}$ Scheper-Hughes (1992) has outlined a similar form of denial amongst mothers of deceased children in Brazil.
} 
seizes children from the other world and 'entrusts' her children to others. ${ }^{31}$ In giving birth, as in farming, the mother again takes from the realm of the gods. In the end, then, the threat made by the mole is nothing less than a demand for restitution. From the point of view of the mole, the child belongs to it, and the biological mother is in the structural position of the slave catcher or the foster mother.

Recently Michelle Gilbert (2010) has analysed the ambivalent naming practices of the Akwapim of Ghana, whereby mothers would require of their children to answer them with a proverb that alluded obliquely to an unspeakably painful event in their mother's past. In this manner, buried memories were 'forgotten and remembered at the same time' (2010: 426), and mothers made their children express what they wanted to say but could not (2010: 431, 433). In a similarly elliptical manner, the symbolic ambiguity or doubling of the mother in the medicinal rites silently evokes the unutterable ambiguity of her position in the political economy of childhood in Oku. As mentioned above, these rites not only resolve social tensions and return the new mother or her infants to a state of normality. In addition, they reveal the tensions inherent in acts of care and nurturance and relations between the generations in $\mathrm{Oku}$; tensions sharpened by the memory of past slavery, the spectre of future fosterage, and its attendant dispersal of the family. The role of the mother is not only fraught with tension during rites of passage: the mother is the passage. She is the passage between the worlds (ntie; literally the earth/ground). ${ }^{32}$ By calling life into this world, she rouses the anger of the gods, whose ultimate answer is to send the mole, the 'thing of the ground', to call life back into the ground. And the mole is not the antithesis, but the mirror of the mother. She is the mother of the underworld and she too is the passage, for she bores the tunnels that forever draw life back to the underworld, the night of memory where the past lies buried.

In contrast to Turner and van Gennep's tripartite model of rites of passage, the rites do not resolve this tension. Rather they bring it to light and suggest that the liminality of childbirth is not inherent to birth itself, but linked to social memories and to contemporary experiences that problematize the role of the mother fundamentally, leaving it unresolved, thereby replacing it within its fractured historical context. ${ }^{33}$ The rites of children's medicine, in other words, are rites of passage, but analysing them purely in terms of the moment of childbirth

\footnotetext{
${ }^{31}$ As Bellagamba (2004) has described with respect to the Gambia, in Mandinka fosterage is referred to as 'entrustment' (karafoo), where the term indexes a wide range of relationships, including patron-client and, in the past, slave-master relationships. The institution of fosterage is thus overdetermined by the institutions with which it was entwined in the colonial and the precolonial past.

${ }^{32}$ Although the dead are said to reside in the forests, lakes and ravines surrounding the kingdom, the 'worlds' of the living and the dead are not spoken of as a duality in $\partial$ blam abkwo. Rather, one speaks of the world/ground (ntie) of the day and the world/ground of the night, which are conceived of simply as two aspects of the same place. The night/day or light/dark opposition is equally often expressed in terms of above/below ground. Like the forest, ravines and the sacred crater-lake, the underside of the ground is a realm of darkness, the night of the world where the sun goes to sleep.

${ }^{33}$ On this point, see also Bloch's (1992) critique of Turner and Van Gennep's model, and cf. Michelle Gilbert's concluding point that the memorial naming practices of Akwapim mothers serve ultimately not to forget, but to remember past pain (2010: 448-9).
} 
and their apparent resolution of this temporary anomaly would amount to a sublimation of tensions that run much deeper in Grassfields kinship and which are much more intractable. At a deeper level, by representing children as preternaturally foreign, the rites evoke the tension between the ideal of the nurturing mother and the social realities of infant death, child abduction, slavery, fosterage and migration: ideals of nurture confronted by forces of exile.

From a synchronic perspective, these rites resolve the paradox of childbirth, providing a resolution to the temporary liminality of the mother and child and returning a world thrown awry by birth to a social status quo. Seen however from a diachronic, historical perspective - through the lens of social memory children's medicine smuggles into ritual practice a recognition of social tensions which are ineffable but nevertheless perennial: the fact that parents who are deeply attached to their children have in the past been forced - if not willing - to part with them, and that they will once again send some of them away; the unremembered, unforgotten past repeating itself in an unresolved, undetermined present. If children eat the ground of $\mathrm{Oku}$, it is because many of them will have to carry it in their bellies rather than being able to tread upon it with their feet. In offering a resolution to the life crisis of childbirth, the rites obscure the deeper truths they remember, but in failing to resolve the tensions that threaten the mother-child bond, they ensure that what is buried is also kept safe, that what is concealed is entrusted to memory.

\section{ACKNOWLEDGEMENTS}

I am grateful to Charles Stafford and Rita Astuti for inviting me to present an earlier version of this article at the Programme in Culture and Cognition (PCC) research seminar at the London School of Economics. For their feedback on the article I am indebted to Andrew Beatty, Maurice Bloch, Stephan Feuchtwang, Murray Last, Isak Niehaus, Gonçalo Santos and Jean-Pierre Warnier. I am also grateful to the Diana, Princess of Wales Memorial Fund for providing research time for this article.

\section{REFERENCES}

Argenti, N. (1999) Is This How I Looked When I First Got Here? Pottery and practice in the Cameroon Grassfields. British Museum Occasional Paper 132. London: Trustees of the British Museum.

_ (2001) 'Kesum-body and the places of the gods: the politics of children's masking and second-world realities in Oku (Cameroon)', Journal of the Royal Anthropological Institute 7 (1): 67-94.

- (2007) The Intestines of the State: youth, violence and belated histories in the Cameroon Grassfields. Chicago IL: University of Chicago Press.

(2010) 'Things that don't come by the road: fosterage, folktales, and memories of slavery in the Cameroon Grassfields', Comparative Studies in Society and History 52 (2): 224-54.

Austen, R. (1983) 'The metamorphoses of middlemen: the Duala, Europeans, and the Cameroon Hinterland, ca 1800-ca 1960', International Journal of African Historical Studies 16 (1): 1-24. 
(1995) 'Slavery and slave trade on the Atlantic coast: the Duala littoral', Paideuma 41: 127-52. (First published in 1977 as 'Slavery among coastal middlemen: the Duala of Cameroon' in S. Miers and I. Kopytoff (eds), Slavery in Africa: historical and anthropological perspectives. Madison WI: University of Wisconsin Press.)

Austen, R. and J. Derrick (1999) Middlemen of the Cameroons Rivers: the Duala and their hinterland c. 1600-c. 1960. Cambridge: Cambridge University Press.

Awasom, N. F. (1984) 'The Hausa and Fulani in the Bamenda Grasslands (19031960)', Thèse de troisième cycle, University of Yaounde.

Bah, Njakoi J. (2000) 'Burial in Oku, Cameroon: an eyewitness account of the death celebration of Fai Ndongdei (Philip Njakoi)', Tribus 49: 49-64.

(2004) 'Ntok Ebkuo: a western Grassfields palace (Cameroon)', Anthropos 99: 435-50.

Bellagamba, A. (2004) 'Entrustment and its changing political meanings in Fuladu, the Gambia (1880-1994)', Africa 74 (3): 383-410.

Bledsoe, Caroline. (1990) "No success without struggle": social mobility and hardship for foster children in Sierra Leone', Man (NS) 25 (1): $70-88$.

Bloch, M. (1992) Prey Into Hunter: the politics of religious experience. Cambridge: Cambridge University Press.

Brain, R. (1972) Bangwa Kinship and Marriage. Cambridge: Cambridge University Press.

Chilver, E. (1961) 'Nineteenth century trade in the Bamenda Grassfieds', Afrika und Übersee 45 (4): 233-58.

(1963) 'Native administration in the West Central Cameroons 1902-1954' in K. Robinson and F. Madden (eds), Essays in Imperial Government Presented to Margery Perham. Oxford: Blackwell.

(1964) 'The Bali-Chamba of Bamenda: settlement and composition', Report No. 2 to the Bali History Committee. Unpublished manuscript.

Chilver, E. and P. Kaberry (1963) 'Traditional government in Bafut, West Cameroon', Nigerian Field 28 (1): 4-30.

(1965) 'Sources of nineteenth-century slave trade. Two comments: the Cameroons Highlands', Journal of African History 6 (1): 117-19.

(1968) Traditional Bamenda: the precolonial history and ethnography of the Bamenda Grassfields. Buea: Ministry of Primary Education and Social Welfare, West Cameroon Antiquities Commission.

Chilver, E. and U. Röschenthaler (2001) Cameroon's Tycoon: Max Esser's expedition and its consequences. New York NY and Oxford: Berghahn Books.

Coe, C. (2008) 'The structuring of feeling in Ghanaian transnational families', City and Society 20 (2): 222-50.

de Rosny, E. (1981) Les yeux de ma chèvre: sur les pas des maîtres de la nuit en pays douala (Cameroun). Paris: Plon.

Diduk, S. (1993) 'Twins, ancestors and socio-economic change in Kejom society', Man (NS) 28 (3): 551-71.

(2001) 'Twinship and juvenile power: the ordinariness of the extraordinary', Ethnology 40 (1): 29-44.

Evans-Pritchard, E. E. (1956) Nuer Religion. Oxford: Clarendon. 
Fardon, R. (1988) Raiders and Refugees: trends in Chamba political development 1750-1950. Washington DC and London: Smithsonian Institution Press.

Feldman-Savelsberg, P., F. T. Ndonko, and B. Schmidt-Ehry (2000) 'Sterilizing vaccines or the politics of the womb: retrospective study of a rumor in Cameroon', Medical Anthropology Quarterly 14 (2): 159-79.

Feldman-Savelsberg, P., F. T. Ndonko and S. Yang (2005) 'Remembering "the troubles": reproductive insecurity and the management of memory in Cameroon', Africa 75 (1): 10-29.

Ferme, M. (2001) The Underneath of Things: violence, history, and the everyday in Sierra Leone. Berkeley CA: University of California Press.

Forni, S. (2001) 'Moulding Culture: pottery and traditions in the Ndop Plain (North West Province Cameroon)'. PhD dissertation, Universita' Degli Studi di Torino, Dipartimento di Scienze Antropologiche, Archeologiche e Storico Territoriali.

Geschiere, P. (1997) The Modernity of Witchcraft: politics and the occult in postcolonial Africa. Charlottesville VA and London: University Press of Virginia.

Gilbert, M. (2010) 'Disguising the pain of remembering in Akwapim', Africa 80 (3): 426-52.

Hutchinson, T. J. (1967) [1861]. Ten Years Wanderings Amongst the Ethiopians. London: Cass.

Hutter, F. (1902) Wanderungen und Forschungen in Nord-Hinterland von Kamerun. Braunschweig: F. Vieweg.

Kaberry, P. M. and E. M. Chilver (1961) 'An outline of the traditional political system of Bali-Nyonga, Southern Cameroons', Africa 31 (4): 355-71.

Koelle, S. W. (1963) [1854]. Polyglotta Africana (P. E. H. Hair and D. Dalby, eds). Graz, Austria: Akademische Druck- und Verlagsanstalt.

Laye, C. (1976) [1953]. L'enfant noir. Paris: Gallimard (Livre de Poche).

Maree, S. and C. Faulkes (2008) 'Cryptomys foxi' in International Union for Conservation of Nature, IUCN Red List of Threatened Species, Version 2010.2, $<$ www.iucnredlist.org >, accessed 3 August 2010.

Masquelier, B. M. (1978) 'Structure and Process of Political Identity: Ide, a polity of the Mentshum Valley (Cameroon)'. PhD thesis, University of Pennsylvania.

Maynard, K. (2004) Making Kedjom Medicine: a history of public health and wellbeing in Cameroon. Westport CT and London: Praeger.

Meyer, B. and P. Geschiere (1999) 'Globalization and identity: dialectics of flow and closure' in B. Meyer and P. Geschiere (eds), Globalization and Identity: dialectics of flow and closure. Oxford: Blackwell, pp. 1-16.

Njoya, A. N. (1995) 'Slavery in the Bamum Kingdom in the nineteenth and twentieth centuries', Paideuma 41: 227-37.

Nkwi, P. N. and J.-P. Warnier (1982) Elements for a History of the Western Grassfields. Yaounde: University of Yaounde.

Nwokeji, G. U. and D. Eltis (2002) 'Characteristics of captives leaving the Cameroons for the Americas, 1822-1837', Journal of African History 43: 191210.

Okri, B. (1991) The Famished Road. London and New York NY: Doubleday.

Rudin, H. (1938) Germans in the Cameroons 1884-1914: a case study in modern imperialism. London: Jonathan Cape. 
Scheper-Hughes, N. (1992) Death Without Weeping: the violence of everyday life in Brazil. Berkeley CA: University of California Press.

Shaw, R. (2002) Memories of the Slave Trade: ritual and the historical imagination in Sierra Leone. Chicago IL: University of Chicago Press.

Tardits, C. (1980) Le Royaume Bamoun. Paris: A. Colin.

Turner, V. (1985) [1969]. The Ritual Process: structure and anti-structure. Ithaca NY: Cornell University Press.

van Slageren, J. (1972) Les origins de l'église évangélique du Cameroun: missions européennes et Christianisme autochtone. Leiden: Brill.

Warnier, J.-P. (1975) 'Pre-Colonial Mankon: the development of a Cameroon chiefdom in its regional setting'. Unpublished $\mathrm{PhD}$ thesis, University of Pennsylvania.

(1985) Echange, développements et hiérarchie dans le Bamenda précolonial (Cameroun). Studien Zur Kulturkunde 76, Wiesbaden: Franz Steiner Verlag.

(1995) 'Slave-trading without slave-raiding in Cameroon', Paideuma 41: 251-72.

(2006) 'The transfer of young people's working ethos from the Grassfields to the Atlantic coast', Social Anthropology 14 (1): 93-8.

(2007) The Pot-King: the body and technologies of power. Leiden and Boston MA: Brill.

(2009) Régner au Cameroun: le roi-pot. Paris: Karthala. (English translation 2007. The Pot-King: the body and technologies of power. Leiden: Brill.)

Wirz, A. (1973a) Vom Sklavenhandel zum Kolonialhandel: Wirtschaftsraüme und Wirtschaftsformen in Kamerun vor 1914. Zurich: Atlantis.

_ (1973b) 'La "Rivière de Cameroun": commerce pré-colonial et contrôle du pouvoir en société lignagère', Revue Française d'Histoire d'Outre-Mer 60 (219): 172-94.

Yufanyi, E. V. (1976) 'God and Ancestor Worship in Kedjom: or, the interactions of Christianity and the traditional beliefs and practices of Vee-Kedjom-Cameroon, with specific reference to the idea of God and ancestor worship'. Unpublished BA dissertation, Bigard Memorial Seminary, Enugu, Nigeria.

\section{ABSTRACT}

Soon after birth, infants in the Cameroon Grassfields chiefdom of Oku are submitted by their parents to rites known generically as 'children's medicine' $(k \partial f u \partial b w a n)$. Ostensibly performed to protect infants from harm and illness, the rites are in fact fraught with tension: they embrace contradictory perspectives regarding the social role of the mother and belie the normative ideal extolling her as a figure of nurture and protection. The article argues that, beyond their overt purpose and symbolism as rites of passage, the rites evoke collective memories of child abductions and contemporary anxieties regarding the anticipated departure of older children and adolescents into foster care or migrant labour. Going beyond a classic tripartite model, the article takes a long-term view that sees lifecrisis rituals as a form of collective memory that bears witness to social tensions that cannot be resolved-in this case the contradictions inherent within the hallowed image of the mother and the compromised nature of parental love. 


\section{RÉSUMÉ}

Peu de temps après la naissance d'un enfant, les parents de la chefferie oku, dans les Grassfields du Cameroun, pratiquent sur leur nourrisson des rites connus sous le nom générique de «médecine des enfants» ( $k \partial f u \partial b w a n)$. Apparemment destinés à protéger le nourrisson contre le mal et la maladie, ces rites sont en fait chargés de tension : ils épousent les perspectives contradictoires concernant le rôle social de la mère et dissimulent l'idéal normatif encensant l'image de la mère nourricière et protectrice. L'article soutient que ces rites, au-delà de leur objet affiché et de leur symbolisme en tant que rites de passage, évoquent des souvenirs collectifs d'enlèvements d'enfants et d'anxiétés contemporaines concernant le départ anticipé des enfants plus âgés et adolescents, placés en famille d'accueil ou travailleurs immigrés. S'écartant d'un modèle tripartite classique, l'article considère à long terme les rituels individuels comme une forme de mémoire collective qui témoigne des tensions sociales impossibles à résoudre, dans le cas présent les contradictions inhérentes à l'image sacralisée de la mère et à la nature compromise de l'amour parental. 